\title{
Evaluation of Cancer Incidence and Age-Adjusted in Regional Cancer Center of Tamilnadu Districts by using Mathematical Technique
}

\author{
K.L. Muruganantha Prasad, B. Thirumeninathan, \\ R. Subramoniam
}

\begin{abstract}
The term cancer does not stand for a single disease, but represents a collection of diseases characterized by uncontrolled cell proliferation. Now a days cancer is one of the main disease to affect the human beings. Due to this is causes death. It is a challenging one to the society for their health problem. The main objective is to explore the design and trends of the cancer incidence in location of the nine regional cancer centers and cancer treatment facilities in the area. (ie., Coimbatore, Kanniyakumari, Salem, Thanjavur, Tirunelveli, Madurai, Trichy, Chennai, Kanchipuram).The cancer cases were separated district wise regional cancer centers for specific cancer sites and age-standardized incident rates were calculated for females. By using Mathematical Technique we found to the cancer incidence and age adjusted of cancer. ie) which district wise regional cancer centers higher in the cancer incidence and age adjusted and which district wise regional cancer centers least in the cancer incidence and age adjusted?
\end{abstract}

Keywords--- Cancer, Age-standardized Rates and Incidence Rates Formulae, Mathematical Technique - ANOVA Table.

\section{INTRODUCTION}

Cancer is a seemingly unpredictable illness that is prevalent among adults and children around the world. In fact, one out of every five persons will die as a result of cancer. Cancer begins when normal cells genetically mutate into abnormal cells, which have the mutant gene, oncogene (1) .There are four main stages of cancer: initiation stage, promoted stage, tumor growth stage, and metastatic stage. Initiation involves changes to the genotype of the cell. To become fully cancerous, a cell must be promoted. Tumor growth is the result of the excretion of mitogens called vascular endothelial growth factor, VEGF(Vascular endothelial growth factor), which stimulate the growth of vascular pathways to the cancer cells. At the last stage, cancer becomes metastatic, which results in the flow of cells into the blood stream. Cancer has a major impact on society in the many country and cross the world.(3)

Statistics tell us things such as how many people are diagnosed with and die from cancer each year, the number of people who are currently living after a cancer diagnosis, the average age at diagnosis and the numbers of people who are still alive at a given time after diagnosis. Among many others, the areas of mathematics fully or partially developed in response to demands of biology include branching

Revised Manuscript Received on July 10, 2019.

K.L. Muruganantha Prasad, Department of Mathematics, H.H. The Rajah's College Pudukkottai. T.N, India

B. Thirumeninathan, Research Scholar, H.H. The Rajah's College Pudukkottai. T.N, India

R. Subramoniam, Department of Mathematics, Lekshmipuram College of Arts \& Science, Neyyoor. T.N, India processes, traveling wave solutions of reaction-diffusion systems, Turing bifurcation and diffusive instability, analysis of replicator equations, stochastic coalescent process, evolutionary game theory, and analysis of variance.(4)

Cancer Incidence rate: A Cancer Incidence rate is the number of new cancers of a specific site /type occurring in a specified population during a year, usually expressed as the number per 100,000 population at risk.

$\mathrm{IR}=($ New cancers/population $) * 100,000$.

The population used depends on the rate to be calculated.

Age Specific Rate (ASpR): This refers to the rate obtained by division of the total number of cancer cases by the corresponding estimated population in that age group and sex/site/geographic area/time period and multiplying by 100,000 .

Age Adjusted or Age Standardised Rate (AAR): Most cancers increase to occur as age increases. Therefore the higher the proportion of older population the higher the number of cancers.

$$
A A R=\frac{\sum_{i=1}^{A} a_{i} w_{i}}{\sum_{i=1}^{A} w_{i}}
$$

where, $a_{i}$ is the age specific rate (ASpR)in age class $i$ $\mathrm{W}_{\mathrm{i}}$ is the standard population in age class $\mathrm{i}$

'A' represents number of age intervals.

\section{Material and Data sources}

The incidence rate and age- adjusted of cancer must be estimated from different regional cancer centres.

[ie., Coimbatore, Kanniyakumari, Salem, Thanjavur, Tirunelveli, Madurai, Trichy, Chennai, Kanchipuram]. In this study, the relative information of estimate population for each regional cancer centres and Minimum crude incidence rate, minimum age-adjusted incidence rate and minimum truncated incidence rate were calculated. We estimated for females (all ages)based data from more than three laks and above. The cancer data for the proposed study was collected from the development of an atlas of cancer in India.(2)

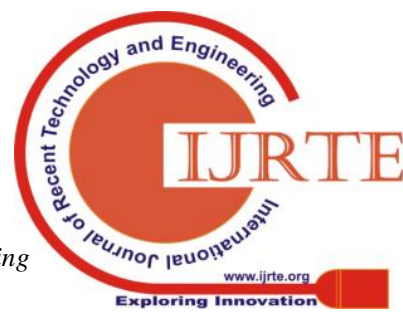




\section{EVALUATION OF CANCER INCIDENCE AND AGE-ADJUSTED IN REGIONAL CANCER CENTER OF TAMILNADU DISTRICTS BY USING MATHEMATICAL TECHNIQUE}

\section{MATHEMATICAL MODEL}

Data for Females the following table:

\begin{tabular}{|c|l|c|c|c|}
\hline S.NO & \multicolumn{1}{|c|}{$\begin{array}{c}\text { REGIONAL } \\
\text { CANCER } \\
\text { CENTRES }\end{array}$} & MCIR & MAAIR & MTIR \\
\hline 1. & I - Coimbatore & 44 & 55 & 134 \\
\hline 2. & II - Kanniyakumari & 45 & 52 & 105 \\
\hline 3. & III - Salem & 46 & 47 & 108 \\
\hline 4. & IV - Thanjavur & 32 & 38 & 89 \\
\hline 5. & V - Tirunelveli & 39 & 42 & 99 \\
\hline 6. & VI - Madurai & 29 & 39 & 91 \\
\hline 7. & VII - Trichy & 35 & 38 & 96 \\
\hline 8. & VIII - Chennai & 29 & 34 & 93 \\
\hline 9. & IX - Kanchipuram & 38 & 40 & 106 \\
\hline
\end{tabular}

* RCC - Regional Cancer Centres ; MCIR- Minimum Crude Incidence Rate; MAAIR- Minimum Age-Adjusted Incidence Rate; MTIR- Minimum Truncated Incidence Rate

\section{ANOVA TABLE AND FORMULAE \& RESULTS}

The analysis of variance procedure is used to test the null hypothesis that the means of three or more populations are the same against the alternative hypothesis that not all population means are the same.The analysis of variance procedure is used to compare three or more population means in a single test.

\section{Analysis of Variance: (ANOVA)}

Analysis of variance is a technique that will enable us to test for the significance of the difference among more than two sample means.

The test is based on the analysis of variation in the data obtained from different samples. The application of one-way ANOVA requires that the following assumptions hold true.

Assumptions of One-Way ANOVA: The following assumptions must hold true to use one-way ANOVA.

1. The populations from which the samples are drawn are (approximately) normally distributed.

2. The populations from which the samples are drawn have the same variance (or standard deviation).

3. The samples drawn from different populations are random and independent.

The ANOVA test is applied by calculating two estimates of the variance of population distributions: the variance between samples and the variance within samples. The variance between samples is also called the mean square between samples. The variance within samples is also called the mean square within samples.(5)

\section{Formulae}

$>$ Sum of all items $(\mathrm{T})=$ $\sum X_{1}+\sum X_{2}+\sum X_{3}+\ldots \ldots$

$>$ Correction factor (C.F) $=\frac{T^{2}}{N}$

$>\mathrm{TSS}=$ Total Sum of Square $=$ Sum of squares of all the items - C.F

$$
=\sum X_{1}^{2}+\sum X_{2}^{2}+\sum X_{3}^{2}+\ldots \ldots-\frac{T^{2}}{N}
$$

SSC $=$ Sum of Squares between Samples

$$
\begin{aligned}
& =\frac{\left(\sum X_{1}\right)^{2}}{n}+\frac{\left(\sum X_{2}\right)^{2}}{n}+\frac{\left(\sum X_{3}\right)^{2}}{n}+\ldots . .-C . F \\
& \text { MSC=Mean squares between } \\
& \text { samples } \\
& =\text { Sum of squares between samples/d.f } \\
& >\quad \text { SSE }=\text { Sum of squares with in } \\
& \text { samples } \quad \text { =Total sum of squares }- \text { Sum of }
\end{aligned}
$$

\begin{tabular}{|c|c|c|c|c|}
\hline $\begin{array}{c}\text { Source of } \\
\text { variation }\end{array}$ & $\begin{array}{l}\text { Sum of } \\
\text { square }\end{array}$ & $\begin{array}{l}\text { Degree of } \\
\text { Freedom }\end{array}$ & $\begin{array}{c}\text { Mean } \\
\text { square }\end{array}$ & F-ratio \\
\hline $\begin{array}{l}\text { Between } \\
\text { Samples }\end{array}$ & SSC & $\mathrm{V}_{1}=\mathrm{K}-1$ & $\begin{array}{l}\mathrm{MSC}= \\
\frac{S S C}{K-1}\end{array}$ & $\begin{array}{l}\mathrm{Fc}= \\
M S C \\
\end{array}$ \\
\hline $\begin{array}{l}\text { With in } \\
\text { Samples }\end{array}$ & SSE & $\mathrm{V}_{2}=\mathrm{N}-\mathrm{K}$ & $\begin{array}{l}\mathrm{MSE}= \\
\frac{S S E}{N-K}\end{array}$ & $M S E$ \\
\hline
\end{tabular}

squares between samples

$$
\begin{aligned}
& \text { samples } \quad \text { MSE = Mean squares with in } \\
& =\text { sum of squares with in samples / d.f } \\
& >\quad \text { Usually we taken 5\% level of } \\
& \text { significance }
\end{aligned}
$$

Conclusion: If $\mathrm{F}_{\text {cal }}<\mathrm{F}_{\text {tab }}$, we accept Null Hypothesis and If $\mathrm{F}_{\mathrm{cal}}>\mathrm{F}_{\mathrm{tab}}$, we reject Null Hypothesis.

Here we take, $\mathrm{H}_{0}$ is Null Hypothesis and $\mathrm{H}_{1}$ is Alternative Hypothesis.

Here K-Number of Samples and N-Total number of items in the given data.

\section{Calculation}

$\mathrm{H}_{0}$ : Cancer centre is not larger.

[There is no significant difference among the Regional cancer center]

$\mathrm{H}_{1}$ : Cancer center is larger.

Given table,

\begin{tabular}{|c|c|c|c|}
\hline RCC & MCIR( $\left.\mathbf{X}_{\mathbf{1}}\right)$ & $\mathbf{M A A I R}\left(\mathbf{X}_{\mathbf{2}}\right)$ & $\mathbf{M T I R}\left(\mathbf{X}_{\mathbf{3}}\right)$ \\
\hline I & 44 & 55 & 134 \\
\hline II & 45 & 52 & 105 \\
\hline III & 46 & 47 & 108 \\
\hline IV & 32 & 38 & 89 \\
\hline V & 39 & 42 & 99 \\
\hline VI & 29 & 39 & 91 \\
\hline VII & 35 & 38 & 96 \\
\hline VIII & 29 & 34 & 93 \\
\hline IX & 38 & 40 & 106 \\
\hline
\end{tabular}

Subtracting by 38 from given data,

\begin{tabular}{|c|c|c|c|c|c|c|}
\hline \multirow{2}{*}{ RCC } & \multicolumn{2}{|c|}{ MCIR } & \multicolumn{2}{c|}{ MAAIR } & \multicolumn{2}{c|}{ MTIR } \\
\cline { 2 - 7 } & $\mathbf{X}_{\mathbf{1}}$ & $\mathbf{X}_{\mathbf{1}}{ }^{2}$ & $\mathbf{X}_{\mathbf{2}}$ & $\mathbf{X}_{\mathbf{2}}{ }^{2}$ & $\mathbf{X}_{\mathbf{3}}$ & $\mathbf{X}_{\mathbf{3}}{ }^{2}$ \\
\hline I & 6 & 36 & 17 & 289 & 96 & 9216 \\
\hline II & 7 & 49 & 14 & 196 & 67 & 4489 \\
\hline III & 8 & 64 & 9 & 81 & 70 & 4900 \\
\hline IV & -6 & 36 & 0 & 0 & 51 & 2601 \\
\hline V & 1 & 1 & 4 & 16 & 61 & 3721 \\
\hline VI & -9 & 81 & 1 & 1 & 53 & 2809 \\
\hline VII & -3 & 9 & 0 & 0 & 58 & 3364 \\
\hline VIII & -9 & 81 & -4 & 16 & 55 & 3025 \\
\hline IX & 0 & 0 & 2 & 4 & 68 & 4624 \\
\hline & $\sum$ & $\sum$ & $\sum$ & $\sum$ & $\sum$ & $\sum$ \\
& $\mathrm{X}_{1}=-$ & $\mathbf{X}_{1}{ }^{2}=357$ & $\mathrm{X}_{2}=43$ & $\mathrm{X}_{2}{ }^{2}=603$ & $\mathrm{X}_{3}=579$ & $\mathrm{X}_{3}{ }^{2}=38749$ \\
\hline
\end{tabular}


Sum of all items $(\mathrm{T})=\sum X_{1}+\sum X_{2}+\sum X_{3}$

$\mathrm{T}=617$.

Correction factor $($ C.F $)=\frac{T^{2}}{N}$

C.F $=14099.59$

TSS=Total Sum of Square

$=$ Sum of squares of all the items - C.F

$=\sum X_{1}^{2}+\sum X_{2}^{2}+\sum X_{3}^{2}-\frac{T^{2}}{N}$

TSS $=25609.41$

$\mathrm{SSC}=$ Sum of Squares between Samples

$$
=\frac{\left(\sum X_{1}\right)^{2}}{n}+\frac{\left(\sum X_{2}\right)^{2}}{n}+\frac{\left(\sum X_{3}\right)^{2}}{n}-C . F
$$

$\mathrm{SSC}=23357.63$

$\mathrm{MSC}=$ Mean squares between samples

$=$ Sum of squares between samples/d.f

$\mathrm{MSC}=11678.81$

$\mathrm{SSE}=$ Sum of squares with in samples

$=$ Total sum of squares - Sum of squares between samples

$\mathrm{SSE}=2251.78$

MSE $=$ Mean squares with in samples

$=$ Sum of squares with in samples / d.f

$\mathrm{MSE}=97.9$

\section{ANOVA Table}

\begin{tabular}{|c|c|c|c|c|}
\hline $\begin{array}{c}\text { Source } \\
\text { of } \\
\text { variatio } \\
\text { n }\end{array}$ & $\begin{array}{l}\text { Sum of } \\
\text { square }\end{array}$ & $\begin{array}{c}\text { Degree } \\
\text { of } \\
\text { Freedo } \\
\text { m }\end{array}$ & $\begin{array}{l}\text { Mean } \\
\text { square }\end{array}$ & F-ratio \\
\hline $\begin{array}{l}\text { Between } \\
\text { Samples }\end{array}$ & $\begin{array}{c}\text { SSC } \\
=23357.6 \\
3\end{array}$ & $\begin{aligned} \mathrm{V}_{1} & =\mathrm{K}- \\
1 & =2\end{aligned}$ & $\begin{array}{l}\mathrm{MSC}= \\
\frac{S S C}{K-1} \\
=11678.8 \\
1\end{array}$ & $\begin{array}{l}\mathrm{Fc}= \\
\frac{M S C}{M S E}\end{array}$ \\
\hline $\begin{array}{l}\text { Within } \\
\text { Samples }\end{array}$ & $\begin{array}{c}\text { SSE } \\
=2251.78\end{array}$ & $\begin{array}{l}\mathrm{V}_{2}=\mathrm{N}- \\
\mathrm{K}=23\end{array}$ & $\begin{array}{l}\mathrm{MSE}= \\
\frac{S S E}{N-K} \\
=97.9\end{array}$ & $\begin{array}{l}=119.2 \\
9\end{array}$ \\
\hline
\end{tabular}

Using the data given above, we are able to plot the Multiple bar channel as given below.

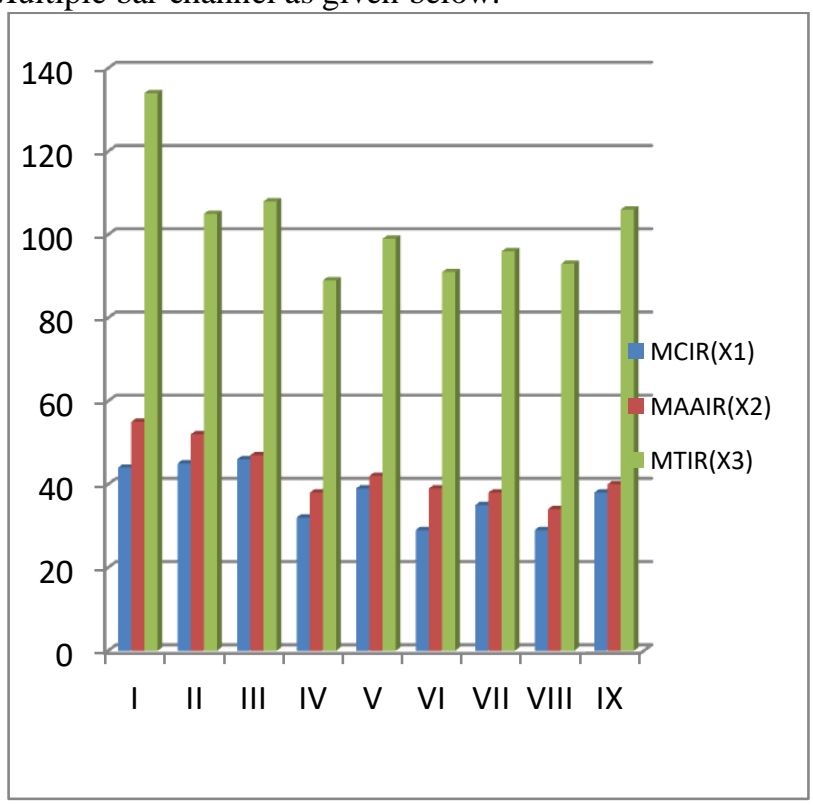

$\mathrm{F}$ for $\mathrm{V}_{1}=2, \mathrm{~V}_{2}=23$ at $5 \%$ level of significance is $\left(\mathrm{V}_{1}, \mathrm{~V}_{2}\right)$ $=(2,23)=5.66$ and Calculated value of $\mathrm{F}$ is $\mathrm{Fc}=119.29$.

Since $\mathrm{F}_{\mathrm{cal}}>\mathrm{F}_{\mathrm{tab}}$, we reject Null Hypothesis $\left(\mathrm{H}_{0}\right)$.Hence we conclude that the cancer centre larger and also there is a significance difference among the regional cancer centre.

\section{REFERENCES}

1. Alberts, B., D. Bray, J. Lewis, M. Raff, K. Roberts, and J. D. Watson. 1994. Molecular biology of the cell 3rd ed. New York: Garland Publishing.

2. A Project of the National Cancer Registry Programme (Indian Council of Medical Research) supported by the World Health Organisation.

3. Kristin Michelle Steely "Applications Of Stochastic Processes To Cancer Research" [p-1-2]

4. Artem S. Novozhilov, Georgy P. Karev, and Eugene V. Koonin*, National Center for Biotechnology Information, National Library of Medicine, National Institutes of Health, Bethesda, MD 20894, “ Biological applications of the theory of birth-and-death Processes".

5. Prem S. Mann Eastern Connecticut State University, Rowan University, John Wiley \& Sons, INC. Seventh Edition INTRODUCTORY STATISTICS

6. David S. Fay $\S$ and Ken Gerow: Department of Molecular Biology, College of Agriculture and Natural Resources, University of Wyoming, Laramie WY 82071, USA \& Department of Statistics, College of Arts and Sciences, University of Wyoming, Laramie WY., 82071

7. Kendall DG. (1949) 'Stochastic Processes and Population Growth', J. of Royal Stat. Soc., Vol. 11, pp. 230-282

8. Karlin S, Taylor HM. (1975) A First Course in Stochastic Processes edn 2nd. San Diego, New York, Boston, London: Academic Press.

9. Whittemore, A. The age distribution of human cancer for carcinogenic exposures of varying intensity. Am.J. Epidemiol., 106,418-432(1977).

10. Jpn. J. Cancer Res.81,1190-1117,November 1990,Naohito Yamaguchi, shawwatanabe, Keiich Maruyama and Toshiteru Okubo, Analysis of Stomach Cancer Incidence by Histologic Subtypes Based on a Mathematical Model of Multistage cancer incidence and exponential Growth 